\title{
RETINYL ACETATE AND MELATONIN IN CHEMOPREVENTION OF MAMMARY CARCINOGENESIS IN FEMALE RATS: METABOLIC CHANGES
}

\author{
M. CHAMILOVÁ, B. BOJKOVÁ, K. KALICKÁ, P. KUBATKA, E. ADÁMEKOVÁ, \\ E. AHLERSOVÁ, I. AHLERS, B. PÁSTOROVÁ \\ Institute of Animal Physiology, Faculty of Science, P. J. Šafárik University and Department of Physiology, \\ University of Veterinary Medicine, Košice, Slovak Republic
}

Received June 5, 2000

Accepted February 7, 2001

Abstract

Chamilová M., B. Bojková, K. Kalická, P. Kubatka, E. Adámeková, E. Ahlersová, I. Ahlers, B. Pástorová: Retinyl Acetate and Melatonin in Chemoprevention of Mammary Carcinogenesis in Female Rats: Metabolic Changes. Acta Vet. Brno, 2001, 70: $57-63$

Combination of chemopreventive substances is expected to be an effective way to combat cancer in the near future. We therefore tested the effect of retinyl acetate (RA) and melatonin (MEL). Nmethyl-N-nitrosourea (MNU) was used to induce mammary carcinogenesis in female SpragueDawley rats $(\mathrm{n}=71)$. NMU was administered intraperitoneally in two doses, each of $50 \mathrm{mg} / \mathrm{kg}$ b.w. between postnatal days 43 and 57. MEL was given in drinking water $(20 \mu \mathrm{g} / \mathrm{ml})$ to group $1(\mathrm{n}=18)$ for 22 weeks, beginning $12 \mathrm{~d}$ before NMU administration. RA administration ( $8.2 \mathrm{mg}$ per animal and day per os) in group $2(\mathrm{n}=18)$ started 11 days before NMU administration and lasted for 22 weeks. Group $3(n=17)$ received both chemopreventive substances and group $4(n=10)$ was left intact. The incidence, latency period, frequency and tumor volume were evaluated in all animals. Selected indices of carbohydrate and lipid metabolism were evaluated in tissue samples and blood serum.

RA+MEL combination decreased the incidence and frequency per group and lengthened the latency period for tumor occurrence.

Both MEL and RA+MEL decreased the serum glucose concentration in tumor-bearing (TB) as well as in non-TB (NTB) animals. In TB animals a decrease of serum cholesterol (CH) in comparison with NTB and intact animals was observed. In the liver of both TB and NTB animals, RA administration led to $\mathrm{CH}$ accumulation, $\mathrm{RA}+\mathrm{MEL}$ combination did not influence this situation. MEL alone and in combination with RA markedly decreased the malondialdehyde concentration in bone marrow of both TB and NTB animals.

The combination of RA + MEL extended the possibilities of a succesfull prevention of experimental mammary carcinogenesis. MEL did not cause substantial side effects in the chronic administration protocol and the decrease in tissue lipid peroxidation predominated among its effects.

Mammary tumors, prevention, rats, retinoids, melatonin

The development, treatment and prevention of mammary gland neoplasms is a problem of utmost importance in contemporary clinical and experimental oncology. Chemoprevention is one of the possibilities how to prevent, inhibit or reverse the process of carcinogenesis; it can be defined as application of natural or synthetic pharmacological substances in order to influence this process. In 1976, Moon et al. were the first to prove that high doses of dietary retinoids inhibited the mammary gland tumor development in experimental animals. Retinoids bind to specific receptors and modulate gene expression. At the molecular level, activation of retinoid receptors can inhibit cell proliferation, induce differentiation and apoptosis in normal as well as in transformed cells (Lippman et al. 1995). The complex of retinoid and nuclear receptor can bind specific DNA sequences of promotor region and activate/inhibit transcription of specific genes (Darmon 1990). Retinoids can inhibit the growth of certain human hormone-dependent mammary gland tumor cell types (Fontana 1987). The oncostatic effect of retinoids results from carcinogen metabolism altering and 
modulating of cell division and cell diferentiation. Retinoids act oncostatically through modification of polyamine and prostanoid biosynthesis and of growth factors activity (E1Bayoumy 1994). Retinoids can increase the production of transforming growth factors $\beta$ (TGF- $\beta$ ) (Glick et al. 1991), stimulate the activity of epidermal growth factor and tumornecrosis factor, act as antioxidant and free-radical deactivators (Lupulescu 1993). Moreover, in human breast cancer cells retinoids increase the intercellular communication in gap junction region and induce apoptosis without p53 gene participation. The most effective retinoids in carcinogen-induced mammary carcinoma reduction are retinyl acetate (RA) and N-(4-hydroxyphenyl)retinamide (4-HPR). RA is effective in 7,12-dimethylbenz(a) anthracene (DMBA) and N-nitroso-N-methylurea (NMU)-induced mammary carcinogenesis but its clinical usage is reduced due to toxic liver damage. The synthetic analogue of all-trans retinoic acid, 4-HPR, does not accumulate extensively in the liver and has no or little toxic effect in experimental animals (Moon et al. 1979), so it appears to be a more suitable candidate for mammary carcinogenesis chemoprevention.

The other important chemopreventive substance is melatonin (MEL), the main pituitary hormone product with crucial role in biological rhythm synchronisation. MEL was reported as an antiproliferative agent in some cancer cell types (Hill and Blask 1988), it acts as an immunostimulator (Maestroni 1993) and a potent free-radical scavenger (Tan et al. 1993). Increased incidence and accelerated tumor growth was observed in experimental animals following pinealectomy. MEL is capable to inhibit neoplasm growth in both spontaneous and chemically-induced experimental mammary tumors.

In an effort to find a suitable and effective chemoprophylaxis of mammary carcinogenesis, many studies investigated the effect of combination of individual effective chemopreventive substances. In our experiment we decided to examine the effect of retinyl acetate and melatonin, individually and in combination, on metabolic parameters in NMU-induced mammary carcinogenesis in female Sprague-Dawley rats. Generally, the investigation of cancer disease requires also the examination of metabolic profile of the host organism. The administration of certain chemopreventive substances can influence metabolism and thus contribute to treatment improvement. Early detection and knowledge of metabolic changes in the organism could be used for the optimalisation of treatment schedule.

\section{Materials and Methods}

Female 33-37-day-old Sprague-Dawley rats (Anlab, Prague, Czech Republic) were used in the experiment. The animals were kept under standard vivarium conditions $\left(23 \pm 2{ }^{\circ} \mathrm{C}\right.$, relative humidity $60-70 \%$, artificial regimen: light: dark $=12: 12 \mathrm{~h}$, light on automatically at 07.00). The rats were fed a standard diet St1230 (Top-Dovo, Dobrá Voda, Slovak Republic) and tap water ad libitum. All experimental groups (except for intact animals) were given N-methyl-N-nitrosourea (NMU, Sigma, Deisenhofen, Germany) in two intraperitoneal doses, each of $50 \mathrm{mg} / \mathrm{kg}$ of b.w. between 43. to 57 . postnatal days (with a seven days interval between the two doses). Chemoprevention was introduced by melatonin (MEL, Biosynth, Staad, Switzerland) administration 12 days and retinyl acetate (RA, Fluka, Buchs, Switzerland) administration 11 days before the first dose of NMU. MEL was given as a solution at $20 \mu \mathrm{g} / \mathrm{ml}$ of tap water from 15.00 to 8.00 (20 mg of MEL were suspended in $0.4 \mathrm{ml}$ of ethanol and diluted in water to the volume of $1 \mathrm{~L}$ ). Two groups of animals were given RA at a dose of $8.2 \mathrm{mg}$ (in $20 \mu \mathrm{l}$ of oil concentrate, $1 \mathrm{ml}$ of oil concentrate contains 1500 I.U. of pure RA, 1 I.U. $=0.34 \mu \mathrm{g}$ of RA) per animal and day per os. Animals were weekly weighed and palpated, and the incidence, latency period, frequency and tumor volume were recorded. The experiment was finished 22 weeks after the first administration of NMU; following overnight fasting. The rats were sacrificed by quick decapitation and lipid and carbohydrate metabolites were analysed in serum (as prepared from mixed blood) and selected organs. Phospholipids (PL) were measured from lipid phosphorus according to B artlett (1952). Cholesterol (CH) was measured from chloroform-methanol extract according to Zlatk is et al. (1953), glycogen according to R oe and Dailey (1966) and malondialdehyde (MDA) was measured in reaction with thiobarbituric acid (S atch et al. 1978). For triacylglycerols and glucose measurement commercial sets of Lachema (Brno, Czech Republic) were used. In serum TG, PL, CH, MDA (as an indicator of lipid peroxidation) and glucose were measured, in liver the content of TG, PL, CH, MDA and glycogen were determined. Concentrations of TG, PL and MDA were measured in bone marrow. Glycogen content was measured in the heart muscle.

The animals were divided into two large groups: tumor-bearing (TB) and non-tumor bearing, (i.e. tumor-free, NTB) with RA, MEL or combined RA and MEL administration. Nine groups with various substances administration were evaluated: 
1) NMU - non-tumor-bearing animals with NMU administration (NTB), $\mathrm{n}$ (the number of animals) =7;

2) NMU - tumor-bearing animals with NMU administration (TB), $n=11$;

3) NMU+RA - non-tumor-bearing animals with NMU and RA administration $(\mathrm{NTB}+\mathrm{RA}), \mathrm{n}=4$;

4) NMU+RA - tumor-bearing animals with NMU and RA administration (TB+RA), n= 14;

5) NMU+MEL - non-tumor-bearing animals with NMU and MEL administration (NTB+MEL), $n=7$;

6) NMU+MEL - tumor-bearing animals with NMU and MEL administration (TB+MEL), $n=11$;

7) NMU+RA+MEL - non-tumor-bearing animals with NMU, RA and MEL administration (NTB+RA+MEL), $\mathrm{n}=10$;

8) NMU+RA+MEL - tumor-bearing animals with NMU, RA and MEL administration (TB+RA+MEL), n= 7; 9) intact animals (INT), $\mathrm{n}=10$

Results were evaluated by Kruskal-Wallis analysis of variance (for $p<0.05$ ).

\section{Results}

In the experiment, the incidence, latency period, frequency and tumor volume were evaluated. RA+MEL combination lowered the frequency and tumor volume and increased the latency period (B ojková et al. 2000).

\section{Serum}

Glucose-No difference between TB and NTB was observed in comparison with intact animals, MEL and combination of RA and MEL reduced serum glucose concentration (Fig. 1)

Triacylglycerols - There was no significant difference between NTB and TB animals. In TB animals, MEL and RA alone and in combination increased serum triglyceride concentration, the significant difference $(p<0.05)$ was observed also between MEL group or in combination of MEL with RA (Fig. 2).

Phospholipids - In NTB, TB and RA+MEL animals PL concentration was decreased as compared to intact animals, RA administration increased PL concentration in both NTB and TB animals.

Cholesterol - Serum CH concentration was decreased in $\mathrm{TB}$ rats in comparison with both INT and NTB animals. Increased $\mathrm{CH}$ concentration was observed in groups with RA (almost to the level of INT) and MEL administration, respectively.

Lipid peroxides - MDA concentration in TB animals was lower as compared to INT rats. MEL and RA+MEL increased MDA concentration in NTB rats, in the latter MDA concentration was increased as compared to NTB+RA. MEL alone

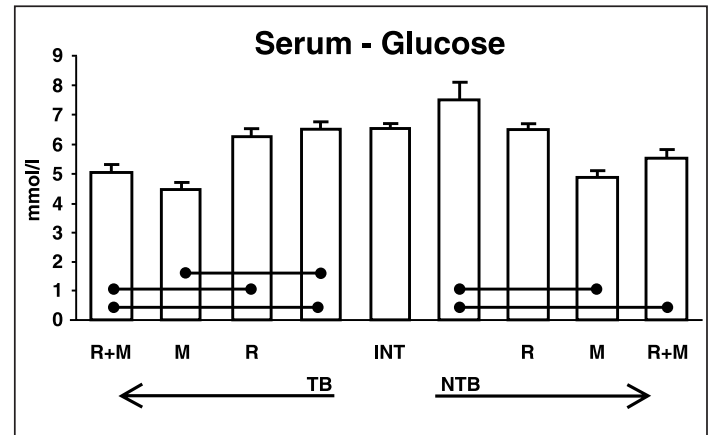

Fig. 1. The concentration of serum glucose in N-methyl-N-nitrosourea - (NMU)-treated non-tumor-bearing (NTB), NMU-treated tumor-bearing (TB), NMU-treated with retinyl acetate (R), NMU-treated with melatonin (M), NMU-treated rats with retinyl acetate and melatonin $(\mathrm{R}+\mathrm{M})$. Values given as mean \pm S.E.M., significance of differences on the level $p<0.05$ depicted as used symbol:

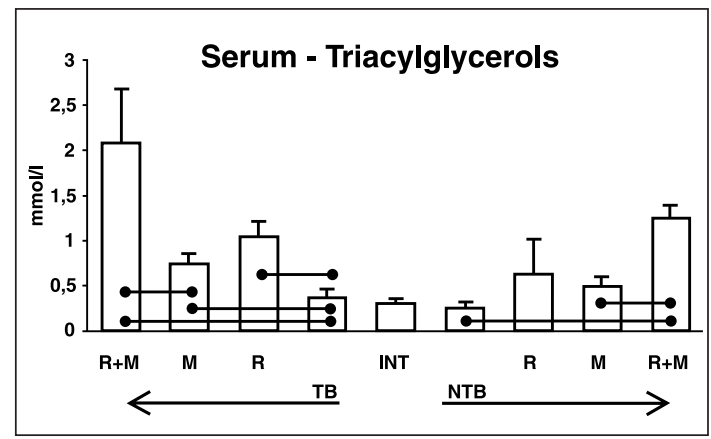

Fig. 2. The concentration of serum triacylglycerols in individual groups of the experiment. For details see Fig.1. and in combination with RA increased serum MDA levels, in the latter the increase was observed also when compared to TB+RA animals. 
Liver

Glycogen - In NTB animals RA alone and in combination with MEL increased the glycogen content, however, MEL alone decreased its content also when compared to RA+MEL. In TB rats RA alone and in combination with MEL increased the glycogen content. MEL administration decreased the glycogen content in both TB and NTB animals, RA and MEL combination decreased the glycogen content when compared to MEL but decreased it when compared to RA.

Triacylglycerols - In TB animals the content of TG was decreased in comparison with INT. In NTB animals $\mathrm{RA}+\mathrm{MEL}$ increased its content also when compared to NTB+MEL rats. In TB animals RA increased TG content. MEL decreased it when compared to RA+MEL in TB animals.

Phospholipids - PL content was increased in both TB and NTB rats in comparison with INT.

Cholesterol - IN TB animals CH content was lower as compared to INT. RA alone and in combination with MEL increased $\mathrm{CH}$ content in both TB and NTB animals but the effect of combination was more expressed (Fig. 3).

Lipid peroxides - In both $\mathrm{TB}$ and NTB animals MDA concentration was higher as compared to INT rats, RA and RA+MEL combination increased MDA concentration in TB as well as NTB animals.

Bone marrow

Triacylglycerols - In TB animals TG concentration was lower than in INT. MEL increased TG concentration in TB, and to lesser (MDA) in individual groups of the experiment. For details see extent also in NTB rats.

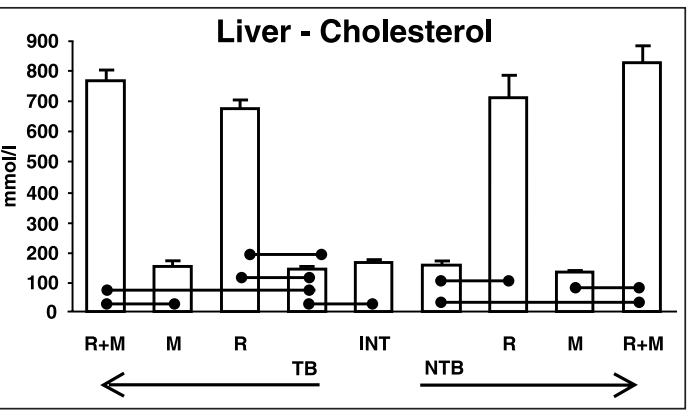

Fig. 3. The content of liver cholesterol in individual groups of the experiment. For details see Fig.1.

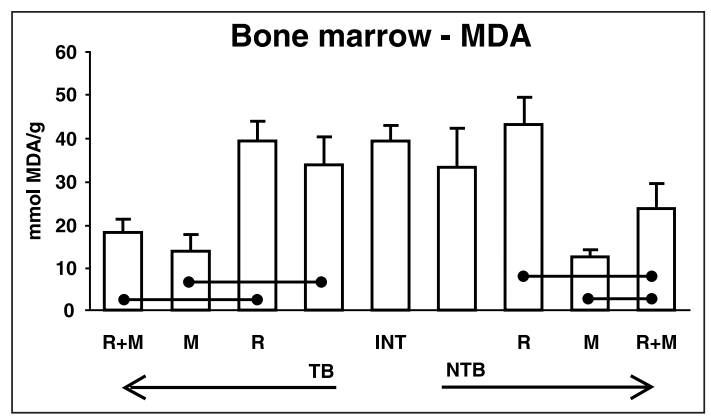

. The concentration of bone marrow malondialdehyde Fig. 1.

Phospholipids - No changes were observed.

Lipid peroxides - The MDA concentration in TB, NTB and INT was almost the same. MEL lowered MDA concentration in both TB and NTB animals, RA + MEL lowered MDA concentration in both TB and NTB in comparison with RA.

Heart muscle

Glycogen - No changes were observed in TB, NTB compared to INT animals. MEL and RA + MEL increased glycogen content in NTB rats and the latter also in TB rats.

\section{Discussion}

Better understanding of chemically-induced mammary carcinogenesis requires the study of tumor initiation and promotion as well as of metabolic changes in the host organism and in the tumor itself. In the tumor-bearing organism, marked changes of carbohydrate and lipid metabolism are observed. 
The tumor growth brings about similar changes in the host organism as chemical carcinogen does; marked changes were found in lipid metabolism (An is i m ov 1987). In women with breast cancer serum TG concentration and concentration of lipoproteins with very low density (VLDL) increased while the concentration of high density lipoproteins decreased (Kö k o glu et al. 1994). Similar changes were recorded in animal cancer models, too. The total body lipid content decreases due to enhanced lipid mobilisation and oxidation in host tissues. Hypertriglycerolemia and hypocholesterolemia contribute to the characteristic features of patterns of tumorbearing animals. In our experiment we observed the decrease of serum cholesterol in TB animals compared to INT and NTB animals and a reduction of $\mathrm{CH}$ and TG content in the liver of TB animals as compared to INT.

In addition to increased synthesis of triacylglycerols, the increased PL (especially ethanolamine- and choline-glycerophospholipids) can be shown in the tumor - this is associated with proliferation of new tumor cells with altered structure. At present, nuclear magnetic resonance (NMR) has been considered to be a suitable method for qualitative and quantitative identification of changes in new phospholipid composition in cancer disease. NMR spectra of human and experimental mammary carcinogenesis point out the high levels of these phospholipids (Furman et al. 1991). In our experiment, a decrease of serum PL and increase of liver PL content was observed in both TB and NTB animals (with carcinogen application) when compared to INT animals.

MEL can play an important role in the process of carcinogenesis. In addition to its oncostatic and immunomodulative effects, MEL is considered to be a free-radical scavenger, it displays antioxidative properties and can alter host metabolism, too. Vaughan and Vaughan (1993) reported lipogenesis inhibition in rat adipocytes and a depressive influence of MEL to serum $\mathrm{CH}$ of intact rats. In our work, MEL application increased serum $\mathrm{CH}$ and TG concentration in TB animals. The role of MEL as an antioxidative agent was confirmed only partially. MEL decreased MDA concentration in bone marrow of TB animals (the decrease in NTB animals was of less extent) and increased it in serum of TB and NTB animals. Prolonged application of MEL can influence carbohydrate metabolism of patients (Guardiola-Lemaitre 1997). It is important to follow the metabolic influence of chronic MEL application since it may interfere with glucose metabolism. In the present experiment, we observed a decrease of glucose concentration in TB and NTB animals following the long-term MEL intake. MEL decreased glycogen content in the liver of TB and NTB animals below the level of INT animals. On the other hand, in the myocardium of NTB animals glycogen accumulation was observed. This fact (increase of glycogen content in myocardium after MEL administration) was reported also by Mazepa et al. (1999). B ailey et al. (1974) confirmed inhibition of glucose-stimulated insulin secretion after MEL administration. Shima et al. (1997) reported a depressive effect of MEL to hyperglycemia induced by intracerebral administration of 2deoxyglucose.

RA and 4-HPR (fenretinide) were reported to be the most effective retinoids to decrease the incidence and increase the latency period of chemically-induced mammary carcinoma (Moon and Mehta 1989). The toxicity play the main role in the choice of a suitable retinoid. The metabolism and distribution of RA and 4-HPR in rat organism differs. Fenretinide is effective in rat mammary carcinogenesis inhibition as well as in clinical studies carried out in premenopausal women (Decensi et al. 1997). RA is effective in chemically-induced mammary tumors but its clinical usage is limited due to toxic liver damage resulting from retinyl ester accumulation. Fenretinide highly accumulates in breast tissue but reaches only small concentrations in liver (Moon and Mehta 1989). Our 
expriment confirmed the adverse effect of RA on liver metabolic parameters; $\mathrm{CH}$ accumulated in the liver of both TB and NTB rats and the liver MDA concentrations were increased, MEL had no effect on this process. Significant changes of carbohydrate metabolism were observed in group with RA and RA+MEL combination. MEL as well as MEL+RA increased serum glucose concentration in TB and NTB animals. RA administration resulted in glycogen accumulation in the liver of TB as well as NTB animals, $\mathrm{RA}+\mathrm{MEL}$ combination improved this state in TB animals but did not prevented it. RA+MEL administration increased serum MDA levels in both TB and NTB animals. These results confirm the need of a proper analysis of changes in carbohydrate metabolism resulting from the long-term application of MEL. Combination of retinoids with antioestrogens or certain cytokines could contribute to the search for effective chemoprevention.

Finally it can be said that RA+MEL combination appears to be useful in mammary cancer chemoprevention. However, the results obtained so far confirm the risk of adverse effect of RA on the host metabolism. In future, the analysis of MEL and 4-HPR combination should be carried out as 4-HPR is well tolerated in humans. Fenretinide neither reduces the bone density nor increases plasma lipoproteins level, shows no hepatotoxicity and does not cause serious dermatologic reactions (DePalo and Formelli 1995).

\section{Chemoprevencia mamárnej karcinogenézy u samíc potkanov retinyl acetátom a melatonínom: metabolické zmeny}

Kombinácia chemopreventínych látok bude účinnou zbraňou v boji $\mathrm{s}$ rakovinovým $\mathrm{v}$ nasledujúcom storočí. V našom experimente sme sledovali účinok retinyl acetátu (RA) a melatonínu (MEL) v ovplyvnení metabolického profilu zvierat s nádorom aj beznádorových zvierat. Na indukciu mammárnej karcinogenézy u panenských samíc potkanov kmeňa SpragueDawley sme použili N-metyl-N-nitrózoureu (NMU). NMU bolo podané samiciam intraperitoneálne $\mathrm{v}$ dvoch dávkach, každá po $50 \mathrm{mg} / \mathrm{kg}$ hmotnosti medzi ich 43.-57. postnatálnym dňom. Časṫ zvierat pila 12 dní pred a 22 týždňov po aplikácii NMU MEL v pitnej vode v koncentrácii $20 \mu \mathrm{g} / \mathrm{ml}$. Dalšej skupine bolo 11 dní pred a 22 týždňov po dávke NMU podané denne 8,2 mg RA perorálne. Tretia skupina dostávala obe chemopreventívne látky, a posledná skupina zvierat nedostávala žiadnu. Po 22. týždňoch boli zvieratá usmrtené, nádory vybrané, zmerané a uložené. Vyhodnotená bola incidencia, latencia, frekvencia a objem nádorov. Zo vzoriek jednotlivých orgánov a séra boli stanovené vybrané parametre lipidového a sacharidového metabolizmu.

Kombinácia RA+MEL znížila incidenciu a frekvenciu nádorov na skupinu, a zvýšila latenciu nádorov.

V sére u nádorových (TB) a nenádorových (NTB) zvierat MEL aj RA+MEL spôsobili zníženie koncentrácie glukózy. U TB zvierat bolo pozorované zníženie koncentrácie sérového cholesterolu $(\mathrm{CH})$, oproti NTB aj INT zvieratám. V pečeni TB aj NTB zvierat RA spôsobil akumuláciu glykogénu, RA+MEL u TB zvierat znížil obsah glykogénu v pečeni. Taktiež došlo k nahromadeniu sa $\mathrm{CH} v$ pečeni u TB aj NTB zvierat, kombinácia s MEL tento stav neovplyvnila. MEL samotný aj v kombinácii s RA výrazne znížil koncentráciu MDA v kostnej dreni u TB aj NTB zvierat.

Kombinácia RA+MEL rozšírila možnosti úspešnej chemoprevencie experimentálnej mamárnej karcinogenézy. Melatonín pri dlhodobom podávaní nemal podstatnejšie vedlajšie účinky, $\mathrm{v}$ popredí bola jeho účinnostì v znížení lipoperoxidačných procesov.

\section{Acknowledgements}

The project 1/4184/97 was supported by the Grant Science Agency-VEGA, Ministry of Education, Slovak Republic. The experiments were conducted according to the principles provided in the Law No 115/1995 § 24 of Slovak Republic for the Care and Use of Laboratory Animals. 


\section{References}

ANISIMOV, V. N. 1987: Carcinogenesis and aging II, CRC Press, Boca Raton. Florida. pp. 46-52

BAILEY, C. J., ATKINS, T. W., MATTY, A. J. 1974: Melatonin inhibition of insulin secretion in the rat and mouse. Horm. Res. 5: 21-28

BARTLETT, G. R. 1959: Phosphorus assay in column chromatography. J. Biol. Chem. 234: 466-468

BOJKOVÁ, B., KUBATKA, P., MÔCIKOVÁ, K., MNÍCHOVÁ, M., AHLERSOVÁ, E., AHLERS, I. 2000: Effects of retinyl acetate and melatonin on N-methyl-N-nitrosourea-induced mammary carcinogenesis in rats. Folia Biol. (Prague) 46: 73-76

DARMON, M. 1990: The nuclear receptors of retinoic acid. J. Lipid Mediat. 2: 247-256

DECENSI, A., TORRISI, R., GOZZA, A., SEVERI, G., BERTELLI, G., FONTANA, V., PENSA, F., CAROZZO, L., TRAVERSO, A., MILONE, S., DINI, D., COSTA, A. 1999: Effect of fenretinide on bone mineral density and metabolism in women with early breast cancer. Breast Cancer Res. Treatm. 53:145-151

EL-BAYOUMY, K. 1994: Evaluation of chemopreventive agents againts breast cancer and proposed strategies for future clinical intervention trials. Carcinogenesis 15: 2395-2420

FONTANA, J. A. 1987: Interaction of retinoids and tamoxifen on the inhibition of human mammary carcinoma cell proliferation. Exp. Cell Biol. 55: 136-144

FURMAN, E., MARGALIT, R., BENDEL, P., HOROWITZ, A., DEGANI, H. 1991: In vivo studies by magnetic resonance imaging and spectroscopy of the response to tamoxifen of MCF7 human breast cancer implanted in nude mice. Cancer Comm. 3: 287-297

GLICK, A. B., MCCUNE, B. K., ABUlKorem, A., FlAnDERS, K. C., LUMADUE, J. A., SMITH, J. M., SPORN, M. B. 1991: Complex regulation of TGF- expression by retinoid acid in the vitamin A-deficient rat. Development 111: 1081-1086

GUARDIOLA-LEMAITRE, B. 1997. Toxicology of melatonin. J. Biol. Rhythms 6: 697-706

HILL, S. M., BLASK, D. E. 1988: Effects of the pineal hormone melatonin on the proliferation and morphological characteristics of human breast cancer cells (MCF-7) in culture. Cancer Res. 48: 6121-6126

LUPULESCU, 1993: The role of vitamins A,E and C in cancer cell biology. Int. J. Vitam. Nutr.Res. 63: 3-14

KÖKOGLU, E., KARAARSLAN, I., KARAARSLAN, H.M., BALOGLU, H. 1994: Alterations of serum lipids and lipoproteins in breast cancer. Cancer Lett. 82: 175-178

LIPPMAN, S. M., HEYMAN, R. A., KURIE, J. M., BENNER, S. E., HONG, W. K. 1995: Retinoids and chemoprevention: Clinical and basic studies. J. Cell. Bioch. 22: 1-10

MAESTRONI, G. J. 1993: The immunoneuroendocrine role of melatonin. J. Pineal Res. 14: 1-10

MAZEPA, R. C., CUEVAS, M. J., COLLADO, P. S., GONZÁLEZ-GALLEGO, J. 1999: Melatonin increases muscle and liver glycogen content in nonexercised and exercised rats. Life Sci. 66: 153-160

MOON, R. C., MEHTA, R. G. 1989: Chemoprevention of experimental carcinogenesis in animals. Prev. Med. 18 576-591

MOON, R. C., THOMPSON, H. J., BECCI, P. J., GRUBBS, C. J., GANDER, R. J., NEWTON, D. L., SMITH, J. M., PHILLIPS, S. L., HENDERSON, W. R., MULLEN, L. T., BROWN, C. C., SPORN, M. B. 1979: N-(4hydroxyphenyl)retinamide, a new retinoid for prevention of breast cancer in the rat. Cancer Res. 39: 1339-1346

MOON, R. C., KELlOFF, G. J., DETRISAC, C. J., STEELE, V., THOMAS, C. F., SiGMAN, C. C. 1992 : Chemoprevention of MNU-induced mammary tumors in the mature rat by 4-HPR and tamoxifen. Anticancer Res. 12: 1147-1154

PALO de, G., FORMELLI, F. 1995: Risk and benefits of retinoids in the chemoprevention of cancer. Drug Safety 13: $245-256$

REITER, R. J., POEGELler, B., TAN, D. X., CHEN, L. D., MANCHESTER, L., GUERRENO, J. M. 1993: Antioxidant capacity of melatonin: A novel action not requiring a receptor. Neuroendocrinol. Lett. 15: 245-250

ROE, J. H., DAILEY, R. 1966: The determination of glycogen with anthrone reagent. Analyt. Biochem. 15: $245-$ 250

SATCH, K. 1978: Serum lipid peroxide in cerebrovascular disorders determined by a new colorimetric method. Clin. Chim. Acta 90: 37-43

SHIMA, T., CHUN, S.-J., NIIJIMA, A., BIZOT-ESPIARD, J.-G., GUARDIOLA-LEMAITRE, B., HOSOKAWA, M., NAGAI, K. 1997: Melatonin suppresses hyperglycemia caused by intracerebroventricular injection of 2-deoxy-D-glucose in rats. Neurosci. Lett. 226: 119-122

TAN, D. X., CHEN, L. D., POEGGELER, B., MANCHESTER, L. C., REER, R. J. 1993: Melatonin, a potent endogenous hydroxyl radical scavenger. Endocrin. J. 15: 57-60

VAUGHAN, M. K., VAUGHAN, G. M. 1993: Metabolic and thyroidal consequences of melatonin administration in mammals. In: Yu, H.S., Reiter, R.J.: Melatonin - Biosynthesis, Physiological Effects, and Clinical Implications. CRC, Boca Raton, pp.311-347

ZLATKIS, A., ZAK, B., BOYLE, A.J. 1953: A new method for the direct determination of cholesterol. J. Lab. Clin. Med. 41: 486-490 